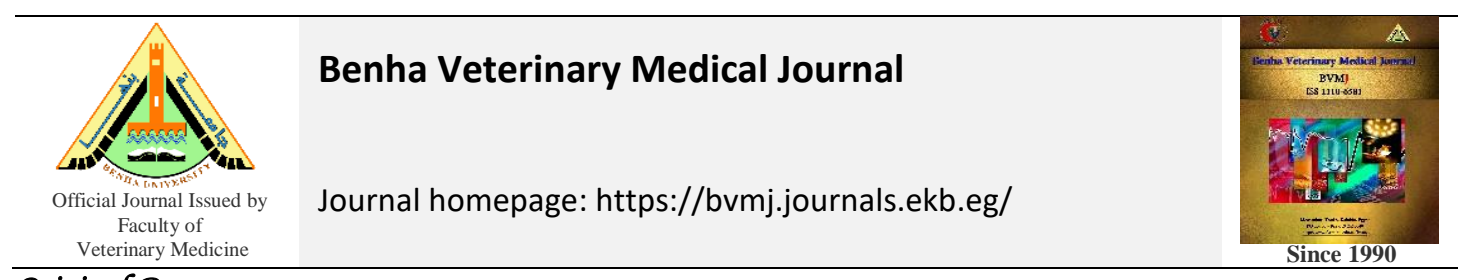

Original Paper

\title{
Comparison of the efficacy of local and imported inactivated combined H9-ND virus vaccines in protection of broiler flocks against H9N2 infection in Egypt
}

Haitham H. Ibrahim ${ }^{1}$ and Manar Seioudy ${ }^{2}$

${ }^{I}$ Poultry Disease Department, Faculty of Veterinary Medicine, Aswan University, Aswan, Egypt.

${ }^{2}$ Central Laboratory of the Veterinary Biologics, Abbassia, Cairo, Egypt

\begin{tabular}{l} 
ARTICLE INFO \\
\hline Keywords \\
Avian Influenza \\
Broiler \\
Imported vaccine \\
Local vaccine \\
\\
\hline Received $07 / 02 / 2020$ \\
Accepted $19 / 03 / 2020$ \\
Availa6le On-Line \\
18/07/2020
\end{tabular}

\begin{abstract}
This study was conducted to compare the efficacy of two combinedH9-ND virus vaccines, one imported and the other local, through two experiments. The first experiment was conducted in the laboratory using 150 one day old chicks divided into 3 groups, the first two groups were vaccinated by the imported and local vaccines, respectively at one day old, the third group was kept as negative control. The antibodies against $\mathrm{H} 9 \mathrm{~N} 2$ virus were detected and measured by $\mathrm{HI}$ test at 14-, 21 - and 28-dayspost-vaccination. At 21 days, each vaccinated group was divided into two sub-groups; the $1^{\text {st }}$ waskept unchallenged, and the $2^{\text {nd }}$ was challenged with the circulating local H9N2 virus strain. In the chicken isolators, cloacal and tracheal swaps were taken at 2-, 4- and 6-days post-challenge to detect the shedding virus using real-time RT-PCR. The second experiment was in a commercial broiler flock contain 432,000 chickens placed in 16 pens. The broiler chickens were divided into 2 groups; each group received a different commercial H9-ND vaccine at the $1^{\text {st }}$ day and the humeral immunity was measured at 14-, 21 and 28-daysby HI test. The results showed that the locally produced vaccine provided a significant higher immune response in both lab. and field experiments and the virus shedding was stopped early (at $4^{\text {th }}$ day post-challenge in cloacal swap) in the group vaccinated by local vaccine. In conclusion, the vaccine prepared from local isolate in Egypt is preferred than imported vaccine in the control of the Avian influenza
\end{abstract}

\section{INTRODUCTION}

Avian influenza(AIV) is a contagious viral disease, classified as a member of Orthomyxoviridae family where its genome is segmented, single strand negative sense RNA (Jordan et al., 2018).

Avian influenza viruses is divided into three distinct types; $\mathrm{A}, \mathrm{B}$, and $\mathrm{C}$ based on serologic reactions to the internal proteins, principally NP and M1 proteins (Calnek, 1997). Avian influenza viruses are divided into subtypes based on the antigenic relationship in the surface glycoprotein into 18 hemagglutinin (HA) and 11 neuraminidase (NA) with variable combinations. AIV are further classified into two pathotypes known as a highly pathogenic avian influenza virus (HPAIV) and a low pathogenic avian influenza virus (LPAIV) (Capua and Alexander, 2004; Klenk et al., 2008; Saif, 2008).

HPAIV causes fatal systemic infection inducing high mortality up to $100 \%$ in all sectors of domestic bird's broilers, layers and breeders while LPAIV produce asymptomatic infection (Capua and Alexander, 2004). Previous experimental study demonstrated that the inactivated vaccines are capable of inducing antibody response, which help in the protection of the infected birds from the clinical signs and mortalities (Capua and Alexander, 2008).H9N2 avian influenza virus have caused several outbreaks in poultry since 1990 , resulting in high economic losses in Asia and Middle East (Das and Suares, 2007). In Egypt the virus is considered one of the major viral problem affecting the poultry industry since its first official reporting on 2010 till now (El-Zoghby et al., 2012).However, the experimental infection of non-specificpathogen-free chickens with H9N2 virus did not show any clinical symptoms (Mo et al., 1998). Co-infection of H9N2 viruses with either bacteria such as Staphylococcus aureus and Haemophilus paragallinarum or with attenuated coronavirus causing serious disease (Haghighat-Jahromi et al., 2008).

Avian influenza virus infection causes high economic losses in both layers and breeder due to drop in egg production also, sever losses in broilers was reported specially in case of coinfection of other viral or bacterial diseases (Monne et al., 2013). Moreover, it was reported that H9N2 virus causes immunosuppression and alteration to the blood biochemical and hematological parameters in the poultry farms in Egypt(Sultan et al., 2015).The continuous genetic changes, either in the envelope or in the internal genes of the isolates, may result probably from the pressure of vaccination, or other unknown reasons (Banet-Noach et al., 2007; Golender et al., 2008; Perk et al., 2009).

The chicken immune system plays a critical role in broiler chicken performance as it reflects the health status of the broiler flocks. The different pathogens get recognized by special receptors in the vertebrate's cells belong to the pathogen recognition receptors (Elfeil et al., 2012;

* Corresponding author: Haitham H. Ibrahim, Poultry Disease Department, Faculty of Veterinary Medicine, Aswan University, Aswan, Egypt. 
Abouelmaatti et al.,2013;Elfeil et al., 2016).The detection of H9N2 virus shed from the infected bird is an important tool for evaluation of the vaccine effectiveness, as the effective vaccine not only prevents clinical disease, but also reduces the viral shedding, to another susceptible birds (Subtain et al., 2011). The vaccine adjuvant plays a role in stimulation of the cellular immunity in case of inactivated vaccines.

The aim of this study was to compare the effectiveness of two commercial H9-ND vaccines one imported vaccine (imported-1) and the other was produced locally from local circulating strain in Egypt.

\section{MATERIAL AND METHODS}

\subsection{Birds of the lab. experiment:}

A total of 150 one-day old divided into three groups. The $1^{\text {st }}$ group (G1) took the locally prepared H9-ND vaccine. The $2^{\text {nd }}$ group $(\mathrm{G} 2)$ took the imported H9-ND at one day old by s/c injection according to the manufacture recommended dose $(0.3 \mathrm{ml} /$ bird for local vaccine and $0.2 \mathrm{ml} /$ bird for imported vaccine). The $3^{\text {rd }}$ group (G3) was kept as negative control.

The chicken were kept for 30 days with daily observation and about 10 blood samples from each group were collected at 14, 21 and 28 days. At 21 day old 25 chicken from each group were taken to the isolators for challenge with H9N2 virus by dose $0.1 \mathrm{ml}$ per bird of $10^{6} \mathrm{EID} 50$ (Sultan et al., 2015),oropharyngeal and cloacal swaps were taken separately from each group at 2, 4 and 6 days post-challenge for detection of virus shedding using real time RT-PCR.

\subsection{The challenge virus}

The challenge virus is $\mathrm{H} 9 \mathrm{~N} 2$ virus $[\mathrm{A} / \mathrm{CK} / \mathrm{Eg} / 114940 \mathrm{v} /$ NLQP/2011(H9N2)] (GenBank Q440373).The virus titer: $10^{6}$ EID50. Dose: $0.1 \mathrm{ml}$ per bird.

\subsection{The primer of real time RT/PCR test:}

The primer and probe of the real time RT-PCR test were designed according to ( Ben Shabat et al, 2010):

\begin{tabular}{|l|}
\hline H9F: GGAAGAATTAATTATTATTGGTCGGTAC \\
\hline H9R: GCCACCTTTTTCAGTCTGACATT \\
\hline H9PRO: FAM 5-AACCAGGCCAGACATTGCGAGTAAGATCC-3 TAMRA \\
\hline
\end{tabular}

\subsection{The birds of the field Experiment}

A total of 432,000 broiler chickens (Ross broiler) placed in 16 pens each pen has 27000 birds. The broiler chickens divided into 2 groups(A and B), each group took a different commercial $\mathrm{H} 9-\mathrm{ND}$ vaccine at $1^{\text {st }}$ day of life by $\mathrm{I} / \mathrm{M}$ injection using the manufacture recommended dose $(0.3 \mathrm{ml} / \mathrm{bird}$ for local vaccine and $0.2 \mathrm{ml} / \mathrm{bird}$ for imported vaccine). Group A ( $n=216,000$ birds) took locally produced vaccine, while group B $(n=216,000$ birds $)$ took imported vaccine (Imported-I), two fixed pens were chosen to follow up the humeral immunity in the both groups. 30 blood samples were collected from each pen at 14, 21 and 28 days.

\subsection{Vaccines:}

Two types of commercial combined H9-ND inactivated oil adjuvant vaccines, the first was locally produced vaccine prepared from local Egyptian isolate (Ck/EG/114940v/NLQP/11; “GenBank Q440373"). The virus was isolated from a broiler flock, in Monufia governorate, Egypt, in 2011 at the Reference Laboratory for Veterinary Quality Control on Poultry Production, Animal Health Research Institute, Dokki, Giza, Egypt. This virus was selected to be representative of circulating LPAI virus (H9N2) in Egypt. The second was imported H9ND vaccine prepared from (H9N2 Middle East (AI)/Ulster 2C (ND).

\subsection{Serum samples:}

The Serum samples were collected from the vaccinated and non-vaccinated group at 14-, 21- and 28-days post vaccination (DPC).

\begin{tabular}{|c|c|c|c|c|c|c|}
\hline \multirow[t]{2}{*}{ Group No. } & \multirow[t]{2}{*}{ No. of Birds } & \multicolumn{3}{|c|}{ Vaccination regime } & \multirow[t]{2}{*}{ Challenge at 21 days of age } & \multirow[t]{2}{*}{ Assessment of protection } \\
\hline & & Type & Age/days & Dose/bird & & \\
\hline \multirow[b]{2}{*}{1} & 25 & \multirow[b]{2}{*}{ local } & \multirow[b]{2}{*}{ One } & \multirow[b]{2}{*}{$0.3 /$ bird } & ++ & Shedding at 2-,4-, and 6 days \\
\hline & 25 & & & & -- & $\mathrm{HI}$ test \\
\hline \multirow[b]{2}{*}{2} & 25 & \multirow[b]{2}{*}{ imported } & \multirow[b]{2}{*}{ One } & \multirow[b]{2}{*}{$0.2 / \mathrm{bird}$} & ++ & Shedding at 2-,4-, and 6 days \\
\hline & 25 & & & & -- & $\mathrm{HI}$ test \\
\hline \multirow[b]{2}{*}{3} & 25 & \multirow{2}{*}{ Non vaccinated } & \multirow[b]{2}{*}{-------- } & \multirow[b]{2}{*}{----o--- } & ++ & Shedding at 2-,4-, and 6 days \\
\hline & 25 & & & & .- & HI test \\
\hline
\end{tabular}

\subsection{Hemagglutination inhibition (HI) test}

The HI test used to monitor the post vaccination humoral immune response for each vaccine; using an avian influenza H9N2 antigen prepared Me-Vac Company (Salihya, Egypt) from an RLQP isolate (represented the circulating virus in Egypt). Chicken sera were examined for HA-specific antibodies against $\mathrm{H} 9 \mathrm{~N} 2$ virus by $\mathrm{HI}$ test according to OIE manual (OIE, 2005).

\subsection{Challenge experiment:}

At 21 day old 25 birds from each group were challenged in Biosafety Level three chicken isolators, at CLEVB.
The challenged birds received a $10 \mu$ ldose at $10^{6} 50 \%$ egg infective dose (EID50)/10 $\mu$ l via the intranasal route. At 2-, 4- and 6-days post-vaccination(DPC), cloacal and oropharyngeal swabs were collected from each challenged group separately for virus detection and titration by real time RT-PCR

\subsection{RNA extraction and real time RT-PCR:}

Total RNA from cloacal and tracheal swabs collected from vaccinated challenged chickens from groups $A$ and $B$, and from non-vaccinated challenged group using RNA 
extraction kit (Easy Pure Viral DNA/RNA kit), according to the manufacturer's instruction then RT-PCR was done using real time RT-PCR kits (TransScript Probe One-Step qRTPCR Super Mix kits).Briefly, the real-time RT-PCR volume was $25 \mu$ l,containing $12.5 \mu \mathrm{l}$ of $2 \times \mathrm{RT}$-PCR buffer, $1 \mu \mathrm{l}$ of each primer H9FandH9R(10M), $1 \mu$ l of probe H9PRO (3M), $1 \mu \mathrm{l}$ of $25 \times$ RT-PCR Enzyme Mix, $6.51 \mu 1$ of nuclease free water, $2 \mu \mathrm{l}$ of RNA. The RT-PCR assay was run with the following cycling condition: $\mathrm{RT}$ at $45^{\circ} \mathrm{C}$ for $10 \mathrm{~min}$ and $95^{\circ} \mathrm{C}$ for $10 \mathrm{~min}$, followed by 40 cycles of PCR at $95^{\circ} \mathrm{C}$ for $15 \mathrm{sec}$ and $60^{\circ} \mathrm{C}$ for $45 \mathrm{sec}$ (Ben Shabat et al., 2010)

\section{RESULTS}

The HI test results of the lab. experiment

The geometrical mean of HI titers log. 2 in chicken measured at 14,21 , and 28 day of life. The antibodies mean titer, at $14^{\text {th }}$ day were $(3.5 \pm 0.31),(3.2 \pm 0.31)$ and $(1.0 \pm 0.31)$ for G1,G2 and G3 respectively. At $21^{\text {th }}$ day of life, the antibodies were $(4.4 \pm 0.21),(4.0 \pm 0.21)$ and $(0.8 \pm 0.21)$ for $\mathrm{G} 1, \mathrm{G} 2$ and $\mathrm{G} 3$ respectively. At $28^{\text {th }}$ day of life, the antibodies were $(5.0 \pm 0.41),(4.4 \pm 0.41)$ and $(0.0 \pm 0.41)$ for G1, G2 and G3 respectively (Table 2).

The HI test results of the field experiment The geometrical mean of HI titers log.2 in chicken measured at 14,21 , and 28 days of life. The antibodies mean titers at $14^{\text {th }}$ day of life were in the local vaccine was $(3.6 \pm 0.431)$, while the imported-1 vaccine mean antibody titer was (3.4 \pm $0.431)$. The antibodies mean titers at $21^{\text {th }}$ day of life were in the local vaccine was $(4.3 \pm 0.212)$, while the imported-1 vaccine mean antibody titer was $(4.1 \pm 0.212)$. At $28^{\text {th }}$ day of life; the mean antibody titers in the locally produced vaccinated group was $(5.2 \pm 0.24)$; while the imported-1 vaccinated group was $(4.4 \pm 0.24)$ (Table 3$)$.

Results of shedding

At $2^{\text {nd }}$ day post challenge the virus was detected by high concentration in all groups, in both cloacal and tracheal swaps, at $4^{\text {th }}$ day post-challenge the virus detected in both oropharyngeal and cloacal swaps of G2,G3 and only oropharyngeal swap of $\mathrm{G} 1$, at the $6^{\text {th }}$ day post-challenge the virus detected only in non-vaccinated group, while both vaccinated groups were negative in cloacal and oropharyngeal swaps (Table 4).

Table 3 The antibodies mean titers of Imported-1 and locally produced H9N2 vaccine at 14,21 and 28 day of life

\begin{tabular}{lllll}
\hline Group No. & Type of vaccine & \multicolumn{4}{l}{ G.M of HI titer $\log 2$ at days post vaccination } \\
& & $14^{\text {th* }}$ & 21 th & 28 th \\
\hline 1 & local & $3.6 \pm 0.43$ & $4.3 \pm 0.21$ & $5.2 \pm 0.24$ \\
2 & imported & $3.4 \pm 0.43$ & $4.1 \pm 0.21$ & $4.4 \pm 0.24$ \\
\hline *: day of life & & & &
\end{tabular}

Table 2 The antibodies mean titers of Imported-1 and locally produced H9N2 vaccine at 14, 21 and 28 day of life

\begin{tabular}{lllll}
\hline Group No. & Type of vaccine & \multicolumn{4}{l}{ G.M of HI titer $\log 2$ at days post vaccination } \\
& & $14^{\text {th* }}$ & 21 th & 28th \\
\hline 1 & local & $3.5 \pm 0.31$ & $4.4 \pm 0.21$ & $5.0 \pm 0.41$ \\
2 & imported & $3.2 \pm 0.31$ & $4.0 \pm 0.21$ & $4.4 \pm 0.41$ \\
3 & Non vaccinated & $1.0 \pm 0.31$ & $0.8 \pm 0.21$ & $0.0 \pm 0.41$ \\
\hline *: day of life & & & &
\end{tabular}

\section{DISCUSSION}

AIV is one of the most important viral diseases in the industry of poultry and has a worldwide distribution (Stallknecht and Shane, 1988).A large numbers of outbreaks have occurred in Egypt since the first detection (El-Zoghby et al., 2012) these have caused severe health problems and large economic losses.In the present study we demonstrate that the inactivated vaccine either locally prepared or imported are capable of inducing antibody response which come in agreement with Bublot et al. (2007). Our results showed that the mean $\log$ titers at 14 and 21 days of life in the locally prepared H9N2 vaccinated group (prepared from circulating strain in Egypt) has a higher mean antibody titer than the imported-1 vaccine; but the difference were nonsignificant at this stage of life which logic at this early stage of life (Choi et al. 2008; Lee et al. 2011; Khalil et al. 2015). $\frac{\text { Table } 4 \text { the virus shedding in oropharyngeal and cloacal swaps at 2,4and } 6 \text { days post challenge with H9N2 virus using real time RT-PCR }}{\text { Days post challenge }}$

\begin{tabular}{|c|c|c|c|c|c|c|}
\hline & & & \\
\hline & Oropharyngeal & Cloacal & Oropharyngeal & Cloacal & Oropharyngeal & Cloacal \\
\hline $2^{\text {nd }}$ & $\begin{array}{c}+ \\
2.2 \times 10 \\
\text { CT30.7 }\end{array}$ & $\begin{array}{c}+ \\
1.9 \times 10 \\
\text { CT } 33\end{array}$ & $\begin{array}{c}+ \\
2.4 \times 10 \\
\text { CT } 29\end{array}$ & $\begin{array}{c}+ \\
2.1 \times 10 \\
\text { CT } 30\end{array}$ & $\begin{array}{c}+ \\
3.7 \times 10 \\
\text { CT } 25\end{array}$ & $\begin{array}{c}+ \\
3.4 \times 10 \\
\text { CT } 27\end{array}$ \\
\hline $4^{\text {th }}$ & $\begin{array}{c}+ \\
1.2 \times 10 \\
\text { CT35 }\end{array}$ & $\begin{array}{c}- \\
- \\
\text { CT } 40\end{array}$ & $\begin{array}{c}+ \\
1.8 \times 10 \\
\text { CT } 33.5 \\
\end{array}$ & $\begin{array}{c}+ \\
1.2 \times 10 \\
\text { CT } 35 \\
\end{array}$ & $\begin{array}{c}+ \\
2.4 \times 10 \\
\text { CT } 29 \\
\end{array}$ & $\begin{array}{c}+ \\
2.1 \times 10 \\
\text { CT } 30\end{array}$ \\
\hline $6^{\text {th }}$ & $\begin{array}{c}- \\
\mathrm{CT}>40\end{array}$ & $\begin{array}{c}- \\
\mathrm{CT}>40\end{array}$ & $\begin{array}{c}- \\
\mathrm{CT}>40\end{array}$ & $\begin{array}{c}- \\
\mathrm{CT}>40\end{array}$ & $\begin{array}{c}- \\
\mathrm{CT}\end{array}$ & $\begin{array}{c}- \\
\mathrm{CT}\end{array}$ \\
\hline
\end{tabular}

The mean titer at the $28^{\text {th }}$ day of lifein the locally prepared H9N2 vaccinated group has a significant higher mean antibody titer than the imported-1 vaccine. This was confirmed in the previous obtained results (Choi et al., 2008;Sun et al., 2012; Khalil et al., 2015), which showed that the vaccines produced from locally circulating virus in the area provide the optimum protection level and higher mean antibody titer.

The results obtained from this study indicated that there was a good antibodies response against $\mathrm{H} 9 \mathrm{~N} 2$ after one vaccination by the inactivated vaccine. This is coordinated with Lee et al. (2011), who mentioned that a single administration of inactivated H9N2vaccine is very immunogenic and highly protective in laboratory trials using SPF chickens. The Montanide ISA71 adjuvants which are the oil adjuvant of the local vaccine may enhance the early and the higher immune response this agree with that mentioned by Jang et al. (2010).

In our study the shedding pattern of the H9N2 virus after challenge come in agreement with that obtained by Sultan et al. (2015), who reported a marked reduction of virus shedding in the group vaccinated with local vaccine than the other two groups with early stopping of the cloacal and late tracheal shedding.

Our study prove that, for effective vaccination strategy, it is necessary to use a vaccine containing strain that has a 
genetic and antigenic similarity to the circulating field strain which is coordinated with Wood et al. (1985). In addition, our results agreed with Kilany et al. (2016), who found that the titer of the virus shedding via oropharyngeal and cloacal swabs was lower in the vaccinated groups than the unvaccinated challenge one.

\section{CONCULSION}

The vaccines prepared from local circulating virus in an area in Egypt provide better humeral immune response and low virus shedding which turn higher protection level against the suspected infection in the same area.

\section{ACKNOWLEGEMENT}

The authors appreciate Dr. Walid Kilany, Assistant Research in Reference Laboratory for Veterinary Quality Control on Poultry Production (RLQP), Animal Health Research Institute, Dokki, Giza, Egypt.

\section{REFERENCES}

1. Abdel-Glil, M.Y., Mor, S.K., Sharafeldin, T.A., Porter, R.E., and Goyal, S.M. 2014. Detection and characterization of Newcastle disease virus in formalin-fixed, paraffin-embedded tissues from commercial broilers in Egypt. Avian Dis.58(1): 118-123.

2. Abouelmaatti, R.R., Algammal, A.M., Li, X., Ma, J., Abdelnaby, E.A., and Elfeil, W.M.K. 2013. Cloning and analysis of Nile tilapia Toll-like receptors type-3 mRNA. Central Europ. J. Immunol.38(3): 277-282.

3. Aldous, E.W., Mynn, J.K., Irvine, R.M., Alexander, D.J., and Brown, I.H. 2010. A molecular epidemiological investigation of avian paramyxovirus type 1 viruses isolated from game birds of the order Galliformes. Avian Pathol.39(6): 519-524.

4. Banet-Noach, C., Perk, S., Simanov, L., Grebenyuk, N., Rozenblut, E., Pokamunski, S., Pirak, M., Tendler, Y., Panshin, A., 2007. H9N2 influenza viruses from Israeli poultry: a five-year outbreak. Avian Dis. 51: 290-296

5. Ben Shabat, M., Meir, R., Haddas, R., Lapin, E., Shkoda, I Raibstein, I., Perk, S. and Davidson, I. 2010 Development of a real-time TaqMan RT-PCR assay for the detection of H9N2 avian influenza viruses J. Virol. Methods 168: 72-77

6. Bublot, M., Le Gros, F., Nieddu, D., Pritchard, N., Mickle, T.R. and Swayne, D.E. 2007. Efficacy of two H5N9inactivated vaccines against challenge with a recent $\mathrm{H} 5 \mathrm{~N} 1$ highly pathogenic avian influenza isolate from a chicken in Thailand. Avian Dis., 51:332-337.

7. Calnek, B.W.J.B., H.; Charles, W.; Beard Larry R.; Mcdougald, Y. and Saif, M. 1997. Diseases of poultry. $10^{\text {th }}$ Ed. Iowa State University Press, USA. Pp. 291-292.

8. Capua, I., and Alexander, D.J. 2004. Avian influenza: recent developments. Avian Pathol. 33(4): 393-404.

9. Capua, I. and Alexander, D.J. 2008. Avian influenza vaccines and vaccination in birds. Vaccine. 26: 70-73.

10. Choi, J.G., Lee, Y.J., Kim, Y.J., Lee, E.K., Jeong, O.M., Sung, H.W., Kim, J.H., and Kwon, J.H. 2008. An inactivated vaccine to control the current $\mathrm{H} 9 \mathrm{~N} 2$ low pathogenic avian influenza in Korea. J. Vet. Sci. 9(1): 67-74.

11. Das, A. and Suars, D.L. 2007. Development and bench validation of real time reverse transcription polymerase chain reaction protocols for rapid detection of the subtypes $\mathrm{H} 6$, and $\mathrm{H} 9$, and $\mathrm{H} 11$ of avian influenza viruses in experimental samples. J. Vet. Diaga. Invest. 19: 625-634.

12. El-Zoghby, E.F., Arafa, A.S., Hassan, M.K., Aly, M.M., Selim, A., Kilany, W.H., Selim, U., Nasef, S., Aggor, M.G., Abdelwhab, E.M., and Hafez, H.M. 2012. Isolation of H9N2 avian influenza virus from bobwhite quail (Colinus virginianus) in Egypt. Arch.virol.157(6): 1167-1172.

13. Elfeil, W.K., Abouelmaatti, R.R., Sun, C.J., Han, W.Y., Li, X.K., Ma, J.S., Lei, L.C., Liu, S.S., Yang, Y.J., Wang, Y., Mandour, M., Fawzy, M., and Shalaby, M.N. 2012. Identification, cloning, expression of a novel functional Anas platyrhynchos mRNA TLR4. J. Anim. Vet. Adv., 11(10): 1727-1733.

14. Elfeil, W.M.K., Algammal, A.M., Abouelmaatti, R.R., Gerdouh, A., and Abdeldaim, M. 2016. Molecular characterization and analysis of TLR-1 in rabbit tissues. Central Europ. J. Immunol.41(3): 236-242.

15. Golender, N., Panshin, A., Banet-Noach, C., Nagar, S., Pokamunski, S., Pirak, M., Tendler, Y., Davidson, I., Garcia, M., Perk, S., 2008. Genetic characterization of avian influenza viruses isolated in Israel during 2000-2006. Virus Genes37: 289-297

16. Haghighat-Jahromi, M., Asasi, K., Nili, H., Dadras, H. and Shooshtari, H.A.. 2008. Coinfection of avian influenza virus (H9N2 subtype) with infectious bronchitis live vaccine. Arch. Virol.153: 651-655

17. Jang, S. I., H. S. Lillehoj, S. H. Lee, K. W. Lee, E. P. Lillehoj, F. Bertrand, L. Dupuis, and S. Deville. 2010 Montanide ISA 71 VG adjuvant enhances antibody and cell-mediated immune responses to profilin subunit antigen vaccination and promotes protection against Eimeria acervulina and Eimeria tenella. Exp. Parasitol.127:178-183.

18. Jordan, P.C., Stevens, S.K. and Deval J. 2018. Nucleosides for the treatment of respiratory RNA virus infections. Antivir Chem Chemother.26: 1-19

19. Khalil, A., Hussein, H., Tolba, S., and El-Sanousi, A. 2015. Preparation and evaluation of $\mathrm{H} 9 \mathrm{n} 2$ vaccine adjuvated with Montanide ISA71 VG. Global Veterinaria15(4): 670-674.

20. Klenk, H.D., Matrosovich, M.N., and Stech, J. 2008. Avian Influenza. In; Monographs in Virology, vol. 27, S. Karger AG, Basel (eds) Switzerland, PP.292.

21. Lamb, R.A., Collins, P.L., Kolakofsky, D., Melero, J.A., Nagai, Y., Oldstone, M.B.A., Pringle, C.R., and Rima, B.K 2005. Family paramyxoviridae. In Virus Taxonomy. F.C. M., M.M. A., M. J., D. U. and B.L. A. (eds.), Elsevier Academic Press, San Diego, CA, USA. Pp. 655-668.

22. Lee, D.H., Kwon, J.S., Lee, H.J., Lee, Y.N., Hur, W., Hong, Y.H., Lee, J.B., Park, S.Y., Choi, I.S., and Song, C.S. 2011. Inactivated H9N2 avian influenza virus vaccine with gelprimed and mineral oil-boosted regimen could produce improved immune response in broiler breeders. Poultry Sci. 90(5): 1020-1022.

23. Mo, I. P., Song, C.S., Kim, K.S. and Rhee, J.C. 1998. An occurrence of non-highly pathogenic avian influenza in Korea. Proc 4th International Symposium on Avian Influenza, Athens, GA, 379-383

24. Monne, I., Hussein, H.A., Fusaro, A., Valastro, V., Hamoud, M.M., Khalefa, R.A., Dardir, S.N., Radwan, M.I., Capua, I., and Cattoli, G. 2013. H9N2 influenza A virus circulates in H5N1 endemically infected poultry population in Egypt. Influenza Other Respir Viruses 7(3): 240-243.

25. Perk, S., Golender, N., Banet-Noach, C., Shihmanter, E., Pokamunsky, S., Pirak, M., Tendler, Y., Lipkind, M., Panshin, A., 2009. Phylogenetic analysis of hemagglutinin, neuraminidase, and nucleoprotein genes of H9N2 avian influenza viruses isolated in Israel during the 2000-2005 epizootic. Comp. Immunol. Microbiol. Infect. Dis.32: 221238

26. Stallknecht, D. E., and Shane, S. M.1988. Host range of avian influenza virus in free-living birds. Vet. Res. Commun. $12: 125-141$.

27. Saif, Y.M., Fadly, A.M., Glisson, J.R.; McDougald, L.R., Nolan, L.K. and swayne, D.E. 2008. Poultry Disease. $12^{\text {th }}$ Ed. Iowa State University Press, USA. Pp. 153-184.

28. Subtain, S.M., Chaudhry, Z.I., Anjum, A.A., Maqbool, A. and Sadique, U.2011. Study on Pathogenesis of Low Pathogenic 
Avian Influenza Virus H9 in Broiler Chickens. Pakistan J. Zool. 43(5): 999-1008

29. Sultan, A.H., Abd El-Razik, G.A., Allam, S.T., and El-Deeb, A.H. 2015. Inactivated oil emulsion H9N2 vaccine in broiler chickens: Pathogenesis and Clinicopathological studies. Am. J. Res. Commun.3(5): 38-53.

30. Sun, Y., Pu, J., Fan, L., Sun, H., Wang, J., Zhang, Y., Liu, L., and Liu, J. 2012. Evaluation of the protective efficacy of a commercial vaccine against different antigenic groups of H9N2 influenza viruses in chickens. Vet. Microbiol.156(1-2): 193-199.
31. Wood, J. M., KawaokaY., NewberryL. A., BordwellE., and WebsterR. G.1985.Standardization of inactivated H5N2 influenza vaccine and efficacy against lethal A/chicken/Pennsylvania/1370/83infection. Avian Dis., 29(3):867- 872.

32. Kilany, W.H., Ali, A., Bazid, A.I., El-Deeb, A.H., Zain ElAbideen, M.A., El Sayed, M. and El-Kady, M.F. 2016 A Dose-Response Study of Inactivated Low Pathogenic Avian Influenza H9N2 Virus in Specific-Pathogen-Free and Commercial Broiler Chickens . Avian Dis. 60:256-261. 